\title{
ANALISIS SEGMENTASI PENONTON BIOSKOP YOGYAKARTA
}

\author{
Dyna Herlina Suwarto \\ Jurusan Ilmu Komunikasi Universitas Negeri Yogyakarta \\ dynaherlina@uny.ac.id
}

\begin{abstract}
After the long period of the cinema industry decline, the number of audience who visit cinema increases significantly. However, the research to examine the phenomena of audience segmentation is very few. Therefore the study aim is to investigate cinema audience segmentation in Yogyakarta on the basis of the aspects that affects the audience film choice. Furthermore the mix-method approach combining qualitative and quantitative method in sequence was employed to attain the research objective. For the first step, three focus group discussions that involve 20 informants. The second step, survey was conducted involving 454 respondents. The result indicates that there are two different audience segments according their behaviors. The first segment visits the cinema as fun activities in their spare time meanwhile the second segment considers the activity as a cultural interest in order to enjoy the narrative and artistic aspects of a film.
\end{abstract}

Keywords: Cinema, Audience, Segmentation

\begin{abstract}
Abstrak
Setelah periode panjang penurunan industri film nasional, jumlah penonton yang mengunjungi bioskop meningkat secara signifikan. Namun, penelitian untuk menguji fenomena segmentasi penonton yang sangat sedikit. Oleh karena itu penelitian ini bertujuan untuk menyelidiki segmentasi penonton bioskop di Yogyakarta atas dasar aspek yang mempengaruhi pilihan film penonton. Selanjutnya pendekatan campuranmetode yang menggabungkan metode kualitatif dan kuantitatif secara berurutan digunakan untuk mencapai tujuan penelitian. Tahap pertama, dilakukan tiga kali diskusi kelompok terfokus yang melibatkan 20 peserta. Tahap kedua, dilakukan survei terhadap 454 responden. Hasil penelitian menunjukan bahwa terdapat dua segmen penonton berdasarkan prilakunya. Segmen pertama menganggap kunjungan ke bioskop sebagai kegiatan menyenangkan untuk mengisi waktu luang sementara segmen kedua menganggap kegiatan menonton bioskop sebagai kegiatan kebudayaan untuk menikmati narasi dan artistik film.
\end{abstract}

Kata Kunci: Bioskop, Penonton, Segmentasi 


\section{PENDAHULUAN}

Sebagai dampak dari persaingan bisnis dan politik pada tahun 1970-1980an, bioskop di Indonesia dikuasai oleh satu perusahaan besar yaitu PT Sejahtera Raya Nusantara (Subentra Nusantara) sejak tahun 1990 (Sen, 2012). Perusahaan itu mengontrol dua jaringan bioskop besar: Studio 21 and Empire XXI. Studio 21 memiliki 98 bioskop sedangkan Empire XXI terdiri dari 4o bioskop di 31 kota. Tiap bioskop memiliki 4-6 layar/ studio. Sementara itu pesaing mereka Blitz Megaplex, hanya memiliki 6 gedung bioskop di dua kota yaitu Bandung dan Jakarta.

Karena dominasi PT Subentra yang luar biasa, bioskop lokal mati. Terlebih peredaran DVD/VCD illegal membuat penonton enggan pergi ke bioskop. Akibatnya bioskop lokal mati, hanya ada beberapa yang bertahan dengan memutar film berkualitas rendah yang bertema seks dan kekerasan untuk menarik penonton. Jika pada tahun 1990 jumlah bioskop mencapai 2.600 maka pada tahun 2000 hanya tinggal 272 bioskop (Kurnia, 2008: 4).

Jaringan Subentra biasanya hanya memutar film Hollywood tapi sejak tahun 200o, perusahaan ini bersedia memutar film Indonesia seperti 'Daun di Atas Bantal' (1998), 'Petualangan Sherina' (200o), 'Jelangkung' (2001) and 'Ada Apa dengan Cinta' (2001). Sejak saat itu penonton film Indonesia kembali menonton film nasional di bioskop (Nugroho dan Herlina S, 2012)

Saat ini ada sekitar 18 juta penonton pergi ke bioskop secara teratur. Ada peningkatan jumlah penonton yang signifikan sejak tahun 200o, namun jumlah itu sebenarnya hanya $7 \%$ dari penduduk Indonesia (Kemenkraf, 2012). Konsumsi film di Indonesia per kapita termasuk rendah dibandingkan dengan negara lain di Asia. Indeks Indonesian 0,24 sedangkan indeks Japan and India mencapai 1,49 dan 2,72 (www.tourismnews. co.id). Oleh karena sangatlah penting untuk meningkatkan jumlah orang yang hendak menonton film di bioskop.

Sebagai penguasa distribusi film di Indonesia, Subentra mengenakan tiket yang sama untuk semua film. Hal ini membuat produser film Indonesia berada dalam situasi yang sulit karena mereka tidak dapat menggunakan strategi harga untuk memenangkan persaingan. Satu-satunya cara menarik penonton adalah membuat film yang memenuhi selera masyarakat. Karena produser film memiliki keterbatasan sumberdaya maka mereka harus memilih pangsa pasar yang tepat.

Saat ini penelitian mengenai penonton film bioskop sangat jarang dilakukan di Indonesia. Terlebih penelitian yang secara khusus meneliti segmentasi penonton bioskop. Oleh karena itu penelitian ini bertujuan untuk mengetahui segmentasi penonton bioskop di Yogyakarta.

\section{TINJAUAN PUSTAKA}

\section{Penonton Bioskop}

Karya audio visual yang biasa disebut film telah hadir dalam masyarakat Indonesia sejak awal abad ke-19. Film diputar di ruang pemutaran berlayar lebar yang lazim disebut bioskop. Jika pada awal keberadaannya, bioskop film merupakan bangunan semi permanen maka saat ini bioskop mengacu pada ruang pemutaran film yang dilengkapi dengan peralatan pemutar kaset digital dan penyorot gambar di bangunan permanen.

Bioskop-bioskop tersebut memutar film secara teratur pada jadwal tertentu. Orang yang hendak menonton film atau biasa disebut penonton perlu mengikuti jadwal tersebut dan membayar sejumlah uang. Semua bioskop di Indonesia dimiliki oleh swasta maka logika pengelolannya bersifat komersial.

Hanya ada sedikit penelitian mengenai penonton bioskop di Indonesia, terlebih mengenai segmentasi penonton. Survei pasar film juga belum popular di kalangan produser Indonesia. Mereka secara sederhana beranggapan bahwa penonton film di Indonesia adalah anak muda usia 18-35 tahun yang tinggal di kota-kota besar. Mengingat tekanan kompetisi yang semakin tinggi maka para produser seharusnya memiliki informasi yang memadai mengenai 
persepsi dan perilaku penontonnya agar dapat memahami keinginan dan kebutuhan penonton sehingga filmnya laku di pasaran.

\section{Segmentasi}

Peneliti di negara lain telah ada yang melakukan penelitian mengenai segmentasi penonton bioskopsepertiyang dilakukanoleh Cuadrado and Frasquet (1999) di Spanyol. Mereka meneliti beberapa faktor demografi seperti usia, pendidikan, tingkat pendidikan, pekerjaan, jenis kelamin, tempat tinggal dan tempat bioskop. Selain itu kedua peneliti itu juga menanyakan alasan konsumen memilih bioskop tertentu berkaitan dengan fasilitas bioskop seperti tempat parkir, kemudahan akses, cara pemesanan tiket dan ukuran layar.

Penelitian Cuadrado and Frasquet (1999) menyatakan bahwa ada tiga segmen bioskop di Spanyol yaitu: sosial, apathetic (ikutikutan), dan pecinta film. Ketiganya memiliki karakteristik perilaku yang berbeda.

Terbaru, Cuardado et al (2013) kembali mengeksplorasi segmentasi penonton bioskop di Spanyol. Ia menemukan ada empat jenis penonton segmen penonton bioskop komersial yang ke bioskop untuk rekreasi dan hiburan (commercial film audience); segmen penonton film yang elitis yang pergi ke bioskop yang memutar film seni (art film audience), segmen pecinta bioskop, yang lebih baik multiplexes di pusat kota (cinema lovers); dan segmen penonton bioskop yang kegiatan menonton film di multiplexes untuk bersosialisasi (film audience).

Ahli pemasaran Kotler and Keller menekankan pentingnya segmentasi dalam pemasaran produk. Segmen pasar terdiri dari sekelompok pelanggan yang memiliki persamaan kebutuhan dan keinginan. Tugas pemasar adalah untuk mengidentifikasi jumlah dan sifat segmen pasar dan menentukan pasar sasaran (Kotler and Keller, 2012: 214).

Segmentasi konsumen didefinisikan berdasarkan pertimbangan deskripsi karakteristik dan perilaku. Karakteristik tersebut meliputi geografis, demografis, dan psikografis konsumen. Sementara itu, pertimbangan perilaku mempertimbangkan respon konsumen terhadap karakteristik produk, manfaat, cara penggunaan, atau merek.

Penelitian ini hendak merumuskan segmen penonton bioskop di Yogyakarta berdasarkan pertimbangan demografis dan perilaku konsumen yaitu hal-hal yang dipertimbangkan konsumen ketika memilih film di bioskop.

\section{METODE}

Penelitian ini menggunakan pendekatan metode penelitian campuran yaitu kualitatif dan kuantitatif yang dilakukan secara sekuensial dan seimbang (Morgan, 1998 in Sale et al. 2002: 49). Metode penelitian campuran digunakan untuk mendapat pemahaman dan verifikasi yang dalam dan luas (Johnson et al. 2007: 123).

Unit analisa dalam penelitian ini adalah penonton bioskop di Yogyakarta. Bioskop yang dimaksud Empire XXI di Jalan Urip Sumoharjo No 1 Yogyakarta dan Studio 21 Ambarukmo Plaza di Jalan Laksda Adisucipto No 1 Yogyakarta. Sedangkan syarat sebagai partisipan dan responden dalam penelitian ini adalah penonton yang secara teratur menonton film di salah satu bioskop tersebut minimal sebulan sekali. Penonton ditemui pada hari-hari yang berbeda yaitu SeninMinggu karena Jaringan 21 menetapkan harga tiket yang berbeda di hari kerja dan akhir pekan.

Ada dua metode pengumpulan data yang dilakukan. Pertama, penelitian kualitatif menggunakan metode diskusi kelompok terfokus (focus group discussion) untuk mengetahui pola umum penonton mengunjungi bioskop serta alasan mereka memilih film di bioskop. Akan dilakukan beberapa kali diskusi kelompok terfokus, setiap diskusi dihadiri oleh 6-8 informan, hingga data yang diperoleh jenuh (saturated).

Berdasarkan diskusi kelompok terfokus akan disusun kuesioner yang akan digunakan untuk pengambilan data tahap kedua yaitu surves. Jumlah responden yang diperlukan 
untuk merumuskan segmentasi haruslah cukup besar yaitu lebih dari 400 responden (Hair et al, 2010: 219). Para responden ditemui di dua gedung bioskop yang disebutkan di atas di hari kerja dan akhir pekan.

Data yang diperoleh dari diskusi kelompok terfokus dianalisis dengan metode analytical induction dan logical analysis. Metode ini digunakan untuk mendapatkan analisis mendalam. Tahapan analisis data kualitatif dilakukan dalam beberapa tahap yaitu: transkrip diskusi, analisis isi yang mencakup indeksasi, penyimpanan, pengambilan dan mengintrepetasi, selanjutnya adalah penulisan laporan (Bloor, 2002: 59).

Sedangkan data yang diperoleh dari survei dianalisis menggunakan teknik kluster. Teknik ini berusaha mengelompokkan responden dalam beberapa kelompok yang memiliki karakteristik serupa (Hair, 2010: 505). Analisis kluster dikerjakan dengan Two Steps Method yang menggunakan Hierarchical Cluster Analysis (HCA) dan $K$-Means. Metode ini dipilih karena penelitian ini melibatkan lebih dari 200 responden dan data yang dianalisis adalah data nominal. Selanjutnya data juga dianalisis dengan menggunakan between group linkage-method (BIC). Validasi analisis kluster menggunakan ANOVA dan MANOVA.

\section{HASIL DAN PEMBAHASAN}

\section{Analisis Kualitatif}

Diskusi pertama dilakukan pada 25 Juni 2015, diikuti oleh 6 peserta yaitu Andre, Benny, Andi, Endah, Gilang, Ussie. Diskusi selanjutnya dilakukan 2 Juli 2015 yang melibatkan Hadi, Rinto, Tika, Nina, Heru, Santi, Fikri. Diskusi terakhir diselenggarakan 17 Juli 2015 Eni, Adi, Tanti, Rio, Irfan, Nona, Beni.

Seluruh peserta FGD yang mengaku suka menonton film bioskop. Di konsumen umum yang terlibat dalam film FGD dibagi menjadi dua segmen. Segmen pertama adalah 'pecinta film' (film lovers) atau sebagai istilah yang digunakan oleh salah satu peserta adalah 'konsumen film'. Sedangkan segmen kedua adalah 'konsumen bioskop' (movie-goers).

Karakteristik segmen 'pecinta film' ini tidak keberatan menonton film sendirian untukmenikmatifilmdenganpenuh.Sebelum memilih film untuk menonton, mereka mencari berbagai sumber informasi dalam berbagai media. Pilihan film ditentukan oleh keputusan sendiri. Setelah menonton film mereka bersedia untuk menjadi komunikator dengan menulis opini tentang film di blog pribadi, situs jejaring sosial, forum diskusi di internet dan komunikasi interpersonal. Tujuan mereka untuk menonton film yang mendapatkan makna (pesan) dan nilai-nilai kehidupan. Mereka suka mendiskusikan dan merefleksikan makna dari film yang mereka tonton. Dalam banyak kasus, diskusi dan refleksi yang mempengaruhi kehidupan pribadi mereka seperti memberikan motivasi dan membawa ide-ide kreatif.

Segmen kedua, dalam istilah salah satu informan, adalah tempat-konsumen atau penonton bioskop. Jenis konsumen menempatkan film sebagai sarana untuk hiburan. Bioskop adalah tempat alternatif untuk menghabiskan waktu dengan orang yang mereka sukai sebagai teman dan pacar. Meskipun mereka mempertimbangkan pilihan film, tetapi hal yang paling penting adalah kebersamaan dengan temantemannya. Jadi pilihan film mereka sangat dipengaruhi oleh pilihan kelompok. Perbedaan antara 'pecinta bioskop' dan 'konsumen film' ditunjukkan dalam tabel 1.

Analisis kualitatif tidak bisa memberikan informasi rinci tentang perbedaan usia, pendidikan dan frekuensi dari dua segmen. Selanjutnya, analisis ini juga kurang rinci dalam menjelaskan perilaku ketika keduanya membuat keputusan untuk memilih film. Oleh karena itu dilakukan tahap kedua dari fase kuantitatif penelitian ini adalah untuk memberikan informasi yang lebih rinci tentang karakteristik demografi dan perilaku dari kedua segmen ini.. 
Tabel 1

Segmentasi Penonton Bioskop

\begin{tabular}{|c|c|c|c|}
\hline Segmen & $\begin{array}{l}\text { Tujuan Menonton } \\
\text { Film }\end{array}$ & \begin{tabular}{|ll} 
Sumber & Pengambilan \\
Keputusan & \\
\end{tabular} & Prilaku Setelah Menonton Bioskop \\
\hline Pencinta Film & $\begin{array}{l}\text { M e } \mathrm{nd} \text { a } \mathrm{p} \text { a } \mathrm{t} \mathrm{k} \text { a } \mathrm{n} \\
\text { Pengalaman baru. } \\
\text { Men d a a t } \mathrm{kan} \\
\text { makna (pesan } \\
\text { moral) dan nilai- } \\
\text { nilai kehidupan. }\end{array}$ & $\begin{array}{l}\text { Selera diri sendiri berdasarkan } \\
\text { pencarian informasi yang } \\
\text { intensif } \\
\text { Tidak keberatan menonton } \\
\text { film sendirian agar dapat } \\
\text { menikmati film secara } \\
\text { maksimal. }\end{array}$ & $\begin{array}{l}\text { Bersedia menjadi komunikator film } \\
\text { dengan cara menuliskan pendapat } \\
\text { mengenai film di blog pribadi, situs } \\
\text { jejaring sosial, forum perbincangan di } \\
\text { internet dan komunikasi interpersonal. }\end{array}$ \\
\hline $\begin{array}{l}\text { K o n s u m e n } \\
\text { Bioskop }\end{array}$ & $\begin{array}{l}\text { M e } \mathrm{n} \mathrm{d} \text { a } \mathrm{p} \text { a } \mathrm{t} \mathrm{k} \text { a } \mathrm{n} \\
\text { Pengalaman baru } \\
\text { Hiburan } \\
\text { Menghabiskan } \\
\text { waktu santai } \\
\text { dengan teman. }\end{array}$ & $\begin{array}{ll}\text { Keputusan kelompok (teman } \\
\text { menonton) }\end{array}$ & $\begin{array}{l}\text { Jika puas membicarakan sambil } \\
\text { makan setelah menonton film dengan } \\
\text { teman menonton. Jika tidak puas tidak } \\
\text { dibicarakan. }\end{array}$ \\
\hline
\end{tabular}

\section{Analisisis Kuantitatif}

Setelah melakukan analisis kualitatif, peneliti bergerak ke fase kuantitatif. Satu set kuesioner terdiri dari tiga pertanyaan tentang karakteristik pribadi dan 45 pertanyaan yang berkaitan dengan faktor-faktor yang mempengaruhi konsumen sebelum memilih film yang di bioskop. Sehingga di kuesioner tersebut terdiri dari 48 pertanyaan. Kuesioner dibagikan kepada 454 responden yang menemukan di bioskop di Yogyakarta yang Studio 21 dan XXI Empire dari Minggu ke Senin.

Berdasarkan analisis deskriptif, itu mengungkapkan usia, pendidikan dan frekuensi untuk mengunjungi bioskop seperti yang ditunjukkan oleh tabel berikut.

\section{Tabel 2}

\section{Karakteristik Responden Berdasarkan Usia}

\begin{tabular}{|c|c|c|}
\hline Usia & Frekuensi & Persentase \\
\hline$<18$ & 58 & 12,77 \\
\hline $18-23$ & 321 & 70,7 \\
\hline $24-29$ & 42 & 9,25 \\
\hline $30-35$ & 28 & 6,16 \\
\hline $36-41$ & 2 & 0,44 \\
\hline$>41$ & 3 & 0,66 \\
\hline
\end{tabular}

Tabel 3

\section{Karakteristik Responden Berdasarkan Pendidikan}

\begin{tabular}{|c|c|c|}
\hline Pendidikan & Frekuensi & Persentase \\
\hline SD & 3 & 0,66 \\
\hline SMP & 17 & 3,74 \\
\hline SMA & 65 & 14,31 \\
\hline S1 & 352 & 77,5 \\
\hline S2 & 16 & 3,52 \\
\hline S3 & 1 & 0,44 \\
\hline
\end{tabular}

\section{Tabel 4}

\section{Karakteristik Responden Berdasarkan Frekuensi Kunjungan ke Bioskop}

\begin{tabular}{|c|c|c|}
\hline $\begin{array}{c}\text { Kunjungan Ke Bioskop/ } \\
\text { Bulan }\end{array}$ & Frekuensi & Persentase \\
\hline $1-2$ & 379 & 83.48 \\
\hline $3-4$ & 46 & 10,13 \\
\hline $5-6$ & 20 & 4,40 \\
\hline$>6$ & 9 & 1,98 \\
\hline
\end{tabular}

Setelah memahami karakteristik responden, langkah selanjutnya adalah menentukan metode clustering, oleh karena itu peneliti menggunakan Two Steps-BIC Method. Berdasarkan analisis BIC menemukan bahwa responden dikelompokkan menjadi dua kelompok. Cluster pertama yang pecinta film terkandung 
dari $292(64,31 \%)$ responden dan yang kedua yang penonton film terdiri dari $162(35,68 \%)$ responden.

Selanjutkan kedua kluster divalidasi dengan menggunakan analisis MANOVA dengan menggunakan seluruh kriteria: Pillai's Trace, Wilks' Lambda, Hotelling's Trace, and Roy's Largest Root. Berdasarkan kriteria tersebut tingkat signifikasi o,ooo artinya kurang dari o,005 sehingga kluster 1 dan 2 berbeda secara signifikan.

Selain itu, jika menggunakan analisis ANOVA, berdasarkan 48 pertanyaan yang dijawab oleh seluruh responden, baik cluster 1 dan 2 adalah memiliki jawaban yang sama tentang umur, tingkat pendidikan, bioskop frekuensi kunjungan bulanan, rekomendasi teman dan film horor. Sehingga dapat disimpulkan bahwa kedua anggota kelompok memiliki persamaan usia, pendidikan dan frekuensi kunjungan per bulan. Sebagian besar responden yang dibagi dalam dua kelompok adalah mahasiswa dengan usia antara 18-23 yang mengunjungi bioskop sekitar 1-2 kali sebulan. Selanjutnya, terkait dengan pertimbangan memilih film, semua dari mereka selalu mempertimbangkan usulan teman-teman mereka dan film horor. Film horor internasional dan domestik dianggap sebagai genre film yang menarik bagi dua kluster.

Perbedaan perilaku antara dua kelompok yang berkaitan dengan faktor-faktor yang mereka dipertimbangkan sebelum memilih film di bioskop sedikit berbeda. Kedua cluster umumnya memperhatikan sepuluh faktor utama yang disusun dalam urutan sebagai berikut: efek visual, $3 \mathrm{D}$, billboard, pengaturan Film, rumah produksi, musik, film adaptasi dari novel, poster, situs ulasan dan koran sinopsis. Sehingga dapat disimpulkan bahwa mereka suka menonton potongan iklan film (trailler) dengan memperhatikan efekvisul, $3 \mathrm{D}$, latar belakang film, musik (konten visual film) sebelum membuat keputusan. Informasi lain tetang film diperoleh melalui poster dan baliho (iklan) film. Terakhir, konsumen memeriksa kritik dan sinopsis film. Perlu dicatat, film adaptasi dari novel yang merupakan faktor yang menarik bagi konsumen film.
Meskipun kedua kluster memperhatikan hal-halyangsama,namunderajatkepentingan faktor tersebut tidaklah sama. Bagi 'pecinta film' urutan faktor yang dianggap paling penting sampai tidak pentingsebagai berikut: efek visual, musik, baliho, rumah produksi, efek $3 \mathrm{D}$, latar belakang film, film adaptasi dari novel, synopsis koran, ulasan film dari website dan koran sebelum mereka memilih film di bioskop. Sedangkan kluster yang lain, 'konsumen bioskop' menempatkan efek visual pada urutan pertama diikuti dengan efek 3D, latar belakang film, baliho, poster, ulasan film di majalah, rumah produksi, ulasan website dan film adaptasi dari novel.

Perlu dicatat, nilai rata-rata masingmasing pertanyaan untuk tiap kluster berbeda. Nilai rata-rata pada kluster 'pecinta film' sebagian besar di atas 3 sedangkan nilai rata-rata pada kluster 'konsumen bioskop' sebagian besar di bawah 3. Berdasarkan data tersebut dapat disimpulkan bahwa kluster 'pecinta film' memberi perhatian lebih besar pada proses pencarian informasi sebelum memilih film di bioskop dibandingka 'konsumen film'.

\section{SIMPULAN}

Berasal dari analisis kualitatif, dapat diartikan bahwa ada dua kelompok sebagai berikut: kluster satu bernama 'konsumen bioskop' yang terdiri dari penonton bioskop yang pergi untuk mendapatkan pengalaman, hiburan dan mengembangkan hubungan sosial. Sedangkan kluster dua disebut 'pecinta film' yaitu penonton yang menonton bioskop untuk mendapatkan pengalaman baru dan nilai kehidupan moral.

Sejalan dengan studi kualitatif, hasil olah data kuantitatif menggunakan Two-Steps BIC Method Cluster menemukan bahwa ada dua kluster yang memiliki sedikit perbedaan. Kedua kelompok mempertimbangkan trailler film, iklan, ulasan dan cerita dari novel dalam urutan yang berbeda. Berdasarkan kecenderungan skor kuantitatif dua kelompok diketahui bahwa kelompok pecinta film yang dicari informasi lebih intensif daripada klaster lain. Bukti tersebut 
pararel dengan temuan kualitatif yang pecinta film yang lebih hati-hati memilih film berdasarkan penilaian mereka sendiri dari berbagai sumber informasi.

Analisis segmentasi berdasarkan aspek perilaku sebelum memilih film dapat berguna bagi produser film untuk mengatur seperangkat upaya pemasaran film. Di masa depan hal itu perlu dipelajari melakukan studi tentang audiens bioskop yang melibatkan faktor-faktor demografi yang lebih kompleks, motivasi dan kendala untuk menonton film di bioskop. Sehingga pelaku industri film dapat mengetahui informasi tentang segmen penonton bioskop di Indonesia lebih komprehensif.
Keterbatasan penelitian ini hanya dilakukan di dua bioskop sedangkan jumlah bioskop di Yogyakarta bertambah signifikan dalam satu tahun terakhir. Jaringan Subentara menambah lini bioskopnya dengan The Premier yang tidak diikutsertakan dalam penelitian itu. Selain itu, ada dua jaringan bioskop baru yaitu Cinemax (Lippo Group) dan Blitz (PT Graha Layar Mitra). Oleh karena itu diharapkan penelitian serupa dikerjakan lebih lanjut dengan melibatkan lebih banyak tempat penelitian dan jumlah responden. 


\section{DAFTAR PUSTAKA}

Bloor, Michael. 2002. Focus Group Discussion for Social Research, London: Sage Publication.

Cuadrado, Manuel., Frasquet, Marta, 1999. "Segmentation of Cinema Audiences: An Exploratory Study Applied to Young Consumers," Journal of Cultural Economics. Vol 23, pp 257-267

Cuadrado, Manuel., Filimon, Nela., Kerrigan, Finola., Rurale, Andrea, 2013 "Exploring Cinema Attendance Facilitators and Contraints, A Marketing Research Approach". $5^{\text {th }}$ Workshop on Cultural Economics and Management, Cadiz, Spain

Nugroho, Garin., Herlina S, Dyna., 2012. Krisis dan Paradoks Film Indonesia. Jakarta: FFTV-IKJ

Hair, Joseph F., Black, Bill., Babin, Barry., Anderson, Rolph E. and Tatham, Ronald., 2010, Multivariate Data Analysis, $7^{\text {th }}$ ed. Prentice Hall.
Herlina S, Dyna, 2012. "Identifying Key Faktors Affecting Consumer Decision Making Behaviour in Cinema Context: A Mix Method Approach", Proceeding International Conference on Contemporary Bussines and Management - Chulalangkorn Business School.

Johnson, Burke, R., Onwuegbuzie, Anthony J. and Turner, A Lisa, 2007. "Toward a Definition and Mix-Method Research," Journal of Mixed-Method Research, Vol 1, No 2, pp. 112-133

Kurnia, Novi., 2008. Posisi dan Resistensi Ekonomi Politik Perfilman Indonesia, Yogyakarta: Penerbit Fisipol UGM.

Kotler, Philip dan Keller, Kevin Lane., 2012, Marketing Management Fourteen Edition. Prentice Hall.

Sale, E.M. Joana., Lohfekd, Lynee H,. and Brazil, Kevin., 2002. "Revisiting the Quantitative-Qualitative Devate: Implication for Mix-Method Research." Quantity and Quality, Vol 36, pp. 43-53 